\title{
The effects of prenatal sex steroid hormones on sexual differentiation of the brain
}

\author{
Prenatal seks steroit hormonlarının beyindeki cinsiyet farklılaşması üzerine etkileri
}

\author{
Serkan Karaismailoğlu, Ayşen Erdem \\ Department of Physiology, Hacettepe University Faculty of Medicine, Ankara, Turkey
}

\section{Abstract}

Most of the anatomical, physiological and neurochemical gender-related differences in the brain occur prenatally. The sexual differences in the brain are affected by sex steroid hormones, which play important roles in the differentiation of neuroendocrine system and behavior. Testosterone, estrogen and dihydrotestosterone are the main steroid hormones responsible for the organization and sexual differentiation of brain structures during early development. The structural and behavioral differences in the female and male brains are observed in many animal species; however, these differences are variable between species. Animal and human (in vivo imaging and postmortem) studies on sex differences in the brain have shown many differences in the local distribution of the cortex, the gray-white matter ratio, corpus callosum, anterior commissure, hypothalamus, bed nucleus of the stria terminalis, limbic system and neurotransmitter systems. This review aims to evaluate the anatomical, physiological and neurochemical differences in the female and male brains and to assess the effect of prenatal exposure to sex steroid hormones on the developing brain. (J Turkish-German Gynecol Assoc 2013; 14: 163-7)

Key words: Brain gender, sex differences, sex steroid hormones, prenatal development

Received: 28 March, 2013

Accepted: 26 May, 2013
Özet

Beyindeki cinsiyete bağlı anatomik, fizyolojik ve nörokimyasal farklılıkların birçoğu prenatal dönemde oluşmaktadır. Beyindeki seksüel farklılıklar nöroendokrin sistem ve davranışların farklılaşmasında önemli rol oynayan seks steroit hormonlarından etkilenmektedir. Testosteron, östrojen ve dihidrotestosteron erken gelişim döneminde beyindeki yapıların organizasyonundan ve seksüel farklılaşmasından sorumlu olan temel steroit hormonlardır. Dişi ve erkek beyinlerindeki bu yapısal ve davranışsal farklılıklar, birçok hayvan türünde gözlenmekle birlikte türler arasında çeşitlilik göstermektedir. Beyindeki cinsiyete bağlı farklılıklar ile ilgili hayvan ve insan (in vivo görüntüleme ve otopsi) çalışmalan korteksin bölgesel dağılımında, gri-beyaz madde oranında, korpus kallosumda, anterior komissürde, hipotalamusta, stria terminalisin bed nukleusunda, limbik sistemde ve nörotransmitter sistemlerde birçok fark ortaya koymuştur. Bu derlemede dişi ve erkek beyinlerindeki anatomik, fizyolojik ve nörokimyasal farklılıkların değerlendirilmesi ve seks steroit hormonların prenatal maruziyetinin gelişen beyin üzerine etkilerinin incelenmesi amaçlanmıştır.

(J Turkish-German Gynecol Assoc 2013; 14: 163-7)

Anahtar kelimeler: Beyin cinsiyeti, cinsiyet farklılıkları, seks steroit hormonlar, prenatal gelişim

Geliş Tarihi: 28 Mart 2013

Kabul Tarihi: 26 Mayls 2013

\section{Sex steroid hormones and brain gender}

The anatomical and physiological differences between the genders are referred as sexual dimorphism. The term dimorphism (from the Greek word meaning having two forms) indicates phenotypic differences between males and females of the same species. Sexual dimorphism is seen in the reproductive system and in the structure of the central nervous system and cognitive functions as well. Usually, sex steroid hormones are shown to be the main reason for the occurrence of female and male brain differences. Indeed, sexual differentiation is determined by chromosomal, genetic and hormonal factors $(1,2)$. Some studies have shown that sex differences in the central nervous system appear before the onset of the release gonadal hormones during embryonic development. Early genetic events, such as cell migration, can trigger sexual differentiation of brain, independent of hormonal action. After sex steroid hormones and their receptors become available, the influence of gonadal steroids on sexual differentiation become apparent (3). The maternal and fetal derived sex steroid hormones, especially testosterone, estrogen and dihydrotestosterone which play roles in sexual differentiation of neuroendocrine system and behavior, affect the fetal brain during gestation (1).

\section{Production and the mechanism of action of sex steroid hormones}

The typical male phenotype is determined during embryonic development by the sex-determining region Y (Sry) gene, which is located on the Y chromosome. Around the sixth week of gestation, this region of the chromosome activates testicular determining factor (TDF) that initiates testicular differentiation. In the testicles, Leydig cells begin to produce testosterone. Conversely, differentiation of the ovaries in the female fetus begins approximately at week 
8 of gestation (4). The fetal ovary seems to be inactive until late fetal development because it releases a small amount of estrogen prenatally. Furthermore, both female and male fetuses are exposed to high estrogen levels produced by the placenta. Although the gender differences seem to be important between weeks $8-24$ of gestation, this is not the only period for differentiation. The maximum difference in serum testosterone concentration between genders is seen between 12 and 18 weeks. The fetuses are also exposed to small amounts of androgen from the fat tissue and adrenal gland of the fetus and mother $(5,6)$.

All sex steroid hormones are synthesized from cholesterol and carried to their target cells. Because of its small size and lipophilicity, circulating testosterone can cross the blood-brain barrier and pass through the cell membrane. Once testosterone enters the cytoplasm, it binds to its intracellular receptor $(5,7)$. Then, testosterone can be converted to dihydrotestosterone by $5 \alpha$-reductase or to $17 \beta$-estradiol (a form of estrogen) by aromatase enzymes. The classic view suggests that the main mechanism for masculinization of the brain is via the neural aromatization of testosterone. Thus, interestingly, testosterone appears to be converted to an estrogen form and exerts its final effect via binding to estrogen receptors. However, dihydrotestosterone and other androgens also show some effects through androgen receptors. Therefore, the main factor is suggested to be the reciprocal interaction between estrogen receptors and androgen receptors in the male fetal brain (8).

The feminization process is different since the female fetal brain is exposed to high levels of estrogen produced by the placenta and mother. Alpha-fetoprotein, a plasma glycoprotein, binds estrogen and acts as a carrier. Thus alpha-fetoprotein seems to protect the fetal brain from the masculinizing effect of estrogen by preventing its entry into cells. However alpha-fetoprotein does not bind circulating testosterone. Taken together, it might be assumed that feminization may be a passive process, but controversy continues over this process $(2,9)$.

Some clinical studies have indicated that sex steroid hormones influence early human development. For example, individuals with complete androgen insensitivity syndrome (CAIS), who are 46, XY and lack functioning androgen receptors, have normal testes that produce normal male levels of testosterone. Because the target organs cannot respond to androgen, individuals with CAIS are born phenotypically female. As mentioned above, if neural aromatization of testosterone is the only mechanism for masculinization of the brain, then individuals with CAIS should show behavioral masculinization because their estrogen receptors are normal. However, individuals with CAIS display feminine behavior similar to that of normal girls (2). Another example is congenital adrenal hyperplasia (CAH), in which both sexes are exposed to excess adrenal androgen prenatally. Because of the excess androgens, females with $\mathrm{CAH}$ display more male-type behaviors including toy, playmate and activity preferences, even in childhood (6). Autism Spectrum Conditions (ASC), characterized by difficulties with social interaction and empathy, are more common in males. Many studies have indicated that elevated fetal testosterone is a potential risk factor for ASC (10).

\section{Sex differences in the animal brain}

Central nervous system exhibits structural and behavioral differences between genders due to exposure to sex steroid hormones during gestation. Most of the sexual behavioral differences are a part of reproductive behavior, whereas others pertain to cognitive functions; all of these behaviors vary among species. For example, Nottebohm and Arnold (1976) discovered that some brain regions are highly sexually dimorphic in songbirds. Singing is a reproductive behavior and songbirds (canaries, zebra finches, etc.) sing complex songs to attract mates. Interestingly, males but not females can produce intricate songs because of the nuclei in the vocal cord region in the brain that controls singing in songbirds. These nuclei are approximately three (canaries) to five (zebra finch) times larger in volume in males, who sing, compared to females, who do not. These nuclei are sexually dimorphic and sex differences in the volume of these nuclei arise from the action of sex steroid hormones. The sizes of these nuclei are larger in the females exposed to testosterone during development and females sing like males after testosterone treatment $(4,11)$. Similarly, in rodent and non-human primate studies, female animals exposed to testosterone during early development show increased male-typical behavior (12).

Gorski et al. (13) discovered a sexually dimorphic nucleus in the preoptic area of the male rat hypothalamus. The preoptic area, the most distinctive region for sexual morphometric differences, controls copulatory behavior in the male rat. The volume of the sexually dimorphic nucleus of the preoptic area (SDN-POA) is three or five times larger in males than in females. Normally, the SDN-POA is exposed to neuronal apoptosis in newborn rats. But, circulating testosterone, after being converted to estradiol, prevents SDN-POA neuronal apoptosis during the perinatal period. Thus, the volume of the SDN-POA remains larger in males than in females (14).

The anteroventral periventricular (AVPV) nucleus, which is also a sexually dimorphic area, is located in the rat hypothalamus. The volume of the AVPV is approximately two times larger in females than in males. The AVPV has been suggested to play a key role in regulating the phasic secretion of gonadotropinreleasing hormone in female rats. It contains many neurons expressing ovarian steroid hormone receptors $(15,16)$.

\section{Sex differences in the human brain}

Sexual dimorphism is also observed in the human brain. On average, the male brain is larger and heavier than the female brain. Autopsy and in vivo imaging studies have shown that the cerebrum of the men is $8-10 \%$ larger than in women. Regional and structural sex differences have been reported between relative cerebrum sizes. For example, relative to the size of the cerebrum, volumes of the frontal and medial paralimbic cortices are larger in women while men have a larger volume of the frontomedial cortex (17). The superior temporal cortex is also larger in women than men. Broca's area (Brodmann's areas 44 and 45) is located in the ventral and posterior portions of the frontal lobe; it processes information coming from 
Wernicke's area (Brodmann's area 22) and converts it into a pattern for language production. In an autopsy study (10 men and 11 women free of neurological abnormalities), brains were measured using a stereological technique; the results showed that the average volume of Broca's area in women was approximately $20 \%$ larger than in men. This difference may be associated with the view that women have better language skills than men (18). Conversely, men have a greater sulcal volume and greater cerebrospinal fluid volume compared to women (19). Sexual differences are also observed in the blood circulation of brain. Global cerebral blood flow is higher in women than in men, both at rest and during cognitive activity (20). In addition, the gray/white matter ratio, corpus callosum, anterior commissure, hypothalamus, bed nucleus of the stria terminalis, limbic system and neurotransmitter systems also exhibit differences between genders.

\section{The gray/white matter ratio}

The gray matter of the brain consists of neuronal cell bodies and dendrites, while the white matter consists of myelinated axons. Women have greater cortical gray matter volume than men, whereas men have a greater percentage of white matter. In women, the gray/white matter ratio is higher, especially in the cingulate gyrus, insula, frontal, parietal, occipital and temporal lobes as compared with men (21). A study by brain magnetic resonance imaging (MRI) (40 men and 40 women) also showed similar findings for gray and white matter. Additionally, the study indicated that, in men, the left hemisphere has a greater percentage of gray matter than the right hemisphere, while the percentage of white matter shows no difference between the two hemispheres. Women show no asymmetries (19). Additionally, in women, the cortical gray matter volume reaches a peak one or two years earlier than in men (22).

\section{The corpus callosum and anterior commissure}

The corpus callosum consists of nerve fibers, and is located in the middle of the brain where it connects the left and right cerebral hemispheres. It is usually larger in women than in men (23). Women also have a larger anterior commissure, another structure that connects the left and right hemispheres and many brain regions (lateral amygdala, endopiriform cortex, nucleus accumbens etc.), as compared with men (24). Interestingly, an MRI study (12 homosexual men and 10 heterosexual men) showed that the corpus callosum with the isthmus was larger in homosexual than in heterosexual men (25). The massa intermedia, a structure that links the two thalami, is larger in women than in men and is absent more often in men (32\%) than in women (22\%) (26). Taken together, these studies suggest that interhemispheric connectivity may be better in women, although some studies report controversial findings (23).

\section{The hypothalamus}

The hypothalamus, relative to the size of the cerebrum, is larger in men than in women (17). Researchers have reported a region in the human hypothalamus which is analogous to the SDN-POA in the rat. Since the four nuclei are located in the anterior hypothalamus, they are called the interstitial nuclei of the anterior hypothalamus (INAH). The INAH are numbered 1 to 4 (INAH 1-4). Studies have shown that INAH-3 contains more neurons and is larger in men. Moreover, INAH 3 is thought to be analogous to the SDN-POA in the rat (27). In addition, Levay et al. (28) showed that INAH 3 is smaller in homosexual men than in heterosexual men.

\section{The thalamus and suprachiasmatic nucleus}

The thalamus contains a group of large nuclei located in the diencephalon that play a role in sensory perception, as well as in the regulation of limbic and motor functions. A positron emission tomography (PET) study in 120 healthy subjects (65 women and 55 men) showed that the thalamic nuclei are larger in women (29). Women also have a larger caudate nucleus compared to men; this structure is located within the basal ganglia (30). Another structure, the suprachiasmatic nucleus (SCN), lies just above the optic chiasm; it receives direct retinal input and generates circadian rhythms. Vasopressin (VP) and vasoactive intestinal polypeptide (VIP) are present in different subdivisions of the SCN. The VIP subnucleus of the SCN is larger in young adult men than in women (31). However, this sex difference may reverse (the female subnucleus becomes larger) after 40 years of age (32). The VP subnucleus of the SCN has a different shape in men compared to that in women. It has an elongated shape in women, and is more spherical in men (33). Interestingly, the VP subnucleus of the SCN is 1.7 times larger in homosexual men than in heterosexual men (34).

\section{The bed nucleus of the stria terminalis}

The bed nucleus of the stria terminalis (BNST) is a nucleus of the forebrain that receives projections from limbic system nuclei and sends projections to several hypothalamic and brainstem target areas. It may regulate behavioral responses to stress (35). The volume of the encapsulated region of the BNST is larger (97\%) in male rats than in females (36). In humans, a similar sexual difference has also been reported in one study (26 age-matched men and women) showing that the volume of the posteromedial region of the BNST is 2.5 times larger in men than in women. Additionally, they suggested that BNST may play a role in aggressive and sexual behaviors (37). Another study showed that the volume of the central subdivision of the BNST is larger in men than in women. Interestingly, the authors found that the volume of the central subdivision of the BNST in six male-to-female transsexuals was similar to that in other women (38).

\section{The limbic system}

The limbic system is involved in many of our emotions (fear, anger and emotions related to sexual behavior), memory and learning. The most prominent components of the limbic system are the hippocampus and the amygdala. The hippocampus is larger in women than in men. This has been shown by two MRI studies (one with 10 men and 10 women, the other with 35 men and 34 women) $(30,29)$ and a PET study (55 men and 65 women) (29) in healthy people. The amygdala, in contrast to the hippocampus, is larger in men. For example, an MRI study (15 boys and 15 girls) reported that the amygdala was 
larger in boys than in girls aged 7 to 11 years (39). Goldstein et al. (17) also found similar results in 48 healthy adults (21 men and 27 women) using MRI. The amygdala is very important for masculinized social behavior and is affected by testosterone. If a female is exposed to a high dose of testosterone during the neonatal period, she shows masculinized social behavior (40).

\section{Neurotransmitter systems}

The dopaminergic system is involved in the brain reward system, addiction and coordination of motor behavior. Some studies have shown that dopaminergic function is elevated in women due to higher striatal presynaptic dopamine synthesis and increased dopamine transporter availability (this regulates the uptake of dopamine into neurons) $(21,41,42)$. Also, dopamine receptor density in the nucleus accumbens and the striatum is higher in male rats than in female rats during early development (43). A PET study (seven men and six women) showed that women have greater amphetamine-induced dopamine release in the right inferior frontal gyrus and right globus pallidus (44). The higher dopaminergic function in women may be protective against some diseases caused by disturbances in dopaminergic function, such as schizophrenia and alcoholism (21).

The serotonergic system controls complex sensory and motor patterns, and a disruption in serotonin (5-HT) synthesis can trigger schizophrenia, as well as mood, sleep and eating disorders. Sex differences in the serotonin system were first reported nearly 50 years ago in animal models. Rosecrans et al. (45) reported that female rats have higher central serotonin levels than male rats. In humans, some studies have shown similar differences between men and women; for example, whole blood serotonin levels are lower in men (46). In a PET study (eight healthy men and seven healthy women), Nishizawa et al. (47) reported that the mean rate of serotonin synthesis was $52 \%$ higher in men than in women. The 5-HT $1 \mathrm{~A}$ autoreceptor, a subtype of serotonin receptor, is a pharmacological target for antidepressant drugs and plays a role in the modulation of anxiety and depression. A PET study in 25 healthy subjects (12 women and 13 men) showed that 5 - $\mathrm{HT}_{1 \mathrm{~A}}$ receptor numbers were higher in women than in men in certain brain regions such as the dorsal raphe, anterior cingulate cortex, amygdala, medial prefrontal cortex and orbital prefrontal cortex (48). These results may be related to the lower incidence of depression in men.

In addition, regarding the central cholinergic system, which is involved in cognitive function and memory, the expression of muscarinic cholinergic receptors in the cerebral cortex has been found to be higher in women (49). Furthermore, cortical levels of gamma-aminobutyric acid (GABA), which is the major inhibitory neurotransmitter associated with mood and memory, are higher in women than in men (50). The opioid neurotransmitter system controls pain, reward and addictive behaviors. A PET study reported that women have higher mu-opioid receptor binding than men in a number of cortical and subcortical regions (51).

\section{Conclusion}

Understanding sex-specific brain differences between men and women may be an important first step to explain the differ- ences in sex-related behavior patterns. It seems likely that the prenatal hormone environment is responsible for the sexual dimorphism of the brain through effects on neural development.

Ethics Committee Approval: N/A

Informed Consent: $N / A$

Peer-review: Externally peer-reviewed.

Author contributions: Concept - S.K., A.E.; Literature Search S.K., A.E.; Writing - S.K., A.E.

Conflict of Interest: No conflict of interest was decleared by the authors.

Financial Disclosure: No financial disclosure was decleared by the authors.

\section{References}

1. Hutchison JB, Wozniak A, Beyer C, Karolczak M, Hutchison RE. Steroid metabolising enzymes in the determination of brain gender. J Steroid Biochem Mol Biol 1999; 69: 85-96. [CrossRef]

2. Cohen-Bendahan CC, van de Beek C, Berenbaum SA. Prenatal sex hormone effects on child and adult sex-typed behavior: methods and findings. Neurosci Biobehav Rev 2005; 29: 353-84. [CrossRef]

3. Wilson CA, Davies DC. The control of sexual differentiation of the reproductive system and brain. Reproduction 2007; 133: 331-59. [CrossRef]

4. Purves D. Neuroscience. 3rd Ed. Sunderland, MA; Sinauer Associates Inc, 2004: 711-12.

5. Knickmeyer RC, Baron-Cohen S. Fetal testosterone and sex differences in typical social development and in autism. J Child Neurol 2006; 21: 825-45. [CrossRef]

6. Hines M. Sex-related variation in human behavior and the brain. Trends Cogn Sci 2010; 14: 448-56. [CrossRef]

7. Lephart ED. A review of brain aromatase cytochrome P450. Brain Res Brain Res Rev. 1996; 22: 1-26. [CrossRef]

8. Zuloaga DG, Puts DA, Jordan CL, Breedlove SM. The role of androgen receptors in the masculinization of brain and behavior: what we've learned from the testicular feminization mutation. Horm Behav 2008; 53: 613-26. [CrossRef]

9. Bakker J, De Mees C, Douhard Q, Balthazart J, Gabant P, Szpirer $\mathrm{J}$, et al. Alpha-fetoprotein protects the developing female mouse brain from masculinization and defeminization by estrogens. Nat Neurosci 2006; 9: 220-6. [CrossRef]

10. Baron-Cohen S, Lombardo MV, Auyeung B, Ashwin E, Chakrabarti B, Knickmeyer R. Why are autism spectrum conditions more prevalent in males? PLoS Biol 2011; 9: e1001081. [CrossRef]

11. Arnold AP. Developmental plasticity in neural circuits controlling birdsong: sexual differentiation and the neural basis of learning. $\mathrm{J}$ Neurobiol 1992; 23: 1506-28. [CrossRef]

12. Hines M. Prenatal testosterone and gender-related behavior. Eur J Endocrinol 2006; 155 Suppl 1: S115-21. [CrossRef]

13. Gorski RA, Harlan RE, Jacobson CD, Shryne JE, Southam AM. Evidence for the existence of a sexually dimorphic nucleus in the preoptic area of the rat. J Comp Neurol 1980; 193: 529-39. [CrossRef]

14. Hsu HK, Yang RC, Shih HC, Hsieh YL, Chen UY, Hsu C. Prenatal exposure of testosterone prevents SDN-POA neurons of postnatal male rats from apoptosis through NMDA receptor. J Neurophysiol 2001; 86: 2374-80.

15. Davis EC, Shryne JE, Gorski RA. Structural sexual dimorphisms in the anteroventral periventricular nucleus of the rat hypothalamus 
are sensitive to gonadal steroids perinatally, but develop peripubertally. Neuroendocrinology 1996; 63: 142-8. [CrossRef]

16. Simerly RB. Organization and regulation of sexually dimorphic neuroendocrine pathways. Behav Brain Res 1998; 92: 195-203. [CrossRef]

17. Goldstein JM, Seidman LJ, Horton NJ, Makris N, Kennedy DN, Caviness VS Jr, et al. Normal sexual dimorphism of the adult human brain assessed by in vivo magnetic resonance imaging. Cereb Cortex 2001; 11: 490-7. [CrossRef]

18. Harasty J, Double KL, Halliday GM, Kril JJ, McRitchie DA. Languageassociated cortical regions are proportionally larger in the female brain. Arch Neurol 1997; 54: 171-6. [CrossRef]

19. Gur R, Turetsky B, Matsui M, Yan M, Bilker W, Hughett P, et al. Sex differences in brain gray and white matter in healthy young adults: correlations with cognitive performance. Journal of Neuroscience 1999; 19: 4065-72.

20. Gur RC, Gur RE, Obrist WD, Hungerbuhler JP, Younkin D, Rosen AD, et al. Sex and handedness differences in cerebral blood flow during rest and cognitive activity. Science 1982; 217: 659-61. [CrossRef]

21. Cosgrove KP, Mazure CM, Staley JK. Evolving knowledge of sex differences in brain structure, function, and chemistry. Biol Psychiatry 2007; 62: 847-55. [CrossRef]

22. Rapoport JL, Gogtay N. Brain neuroplasticity in healthy, hyperactive, and psychotic children: insights from neuroimaging. Neuropsychopharmacology 2008; 33: 181-97. [CrossRef]

23. Hines M. Gonadal Hormones and Sexual Differentiation of Human Brain and Behavior. Hormones, brain and behavior. 2nd Ed. Boston, MA; Academic Press, 2009: 1870-901.

24. Jones HE, Ruscio MA, Keyser LA, Gonzalez C, Billack B, Rowe R, et al. Prenatal stress alters the size of the rostral anterior commissure in rats. Brain Res Bull 1997; 42: 341-46. [CrossRef]

25. Witelson SF, Kigar DL, Scamvougeras A, Kideckel DM, Buck B, Stanchev PL, et al. Corpus callosum anatomy in right handed homosexual and heterosexual men. Arch Sex Behav 2008; 37: 857-63. [CrossRef]

26. Allen LS, Gorski RA. Sexual dimorphism of the anterior commissure and massa intermedia of the human brain. J Comp Neurol 1991; 312: 97-104. [CrossRef]

27. Byne W, Lasco MS, Kemether E, Shinwari A, Edgar MA, Morgello S, et al. The interstitial nuclei of the human anterior hypothalamus: An investigation of sexual variation in volume and cell size, number and density. Brain Research 2000; 856: 254-8. [CrossRef]

28. LeVay S. A difference in hypothalamic structure between heterosexual and homosexual men. Science 1991; 253: 1034-7. [CrossRef]

29. Murphy DG, DeCarli C, McIntosh AR, Daly E, Mentis MJ, Pietrini P, et al. Sex differences in human brain morphometry and metabolism: an in vivo quantitative magnetic resonance imaging and positron emission tomography study on the effect of aging. Arch Gen Psychiatry 1996; 53: 585-94. [CrossRef]

30. Filipek PA, Richelme C, Kennedy DN, Caviness VS Jr. The young adult human brain: an MRI-based morphometric analysis. Cereb Cortex 1994; 4: 344-60. [CrossRef]

31. Swaab DF, Zhou JN, Ehlhart T, Hofman MA. Development of vasoactive intestinal polypeptide neurons in the human suprachiasmatic nucleus in relation to birth and sex. Brain Res Dev Brain Res 1994; 79: 249-59. [CrossRef]

32. Heath RA. The Praeger Handbook of Transsexuality: Changing Gender to Match Mindset. 1st Ed. Westport, CT; Praeger Publishers, 2006: 24.

33. Swaab DF, Fliers E, Fisser B. The vasopressin containing neurons in the human brain; changes during ageing and senile dementia. $\mathrm{Br} \mathrm{J}$ Clin Pract Suppl 1985; 39: 7-10.
34. Swaab DF, Hofman MA. An enlarged suprachiasmatic nucleus in homosexual men. Brain Res. 1990; 537: 141-8. [CrossRef]

35. McElligott ZA, Winder DG. Modulation of glutamatergic synaptic transmission in the bed nucleus of the stria terminalis. Prog Neuropsychopharmacol Biol Psychiatry 2009; 33: 1329-35. [CrossRef]

36. Hines M, Allen LS, Gorski RA. Sex differences in subregions of the medial nucleus of the amygdala and the bed nucleus of the stria terminalis of the rat. Brain Res 1992; 579: 321-6. [CrossRef]

37. Allen LS, Gorski RA. Sex difference in the bed nucleus of the stria terminalis of the human brain. J Comp Neurol 1990; 302: 697-706. [CrossRef]

38. Zhou JN, Hofman MA, Gooren LJ, Swaab DF. A sex difference in the human brain and its relation to transsexuality. Nature 1995; 378 : 68-70. [CrossRef]

39. Caviness VS Jr, Kennedy DN, Richelme C, Rademacher J, Filipek PA. The human brain age 7-11 years: a volumetric analysis based on magnetic resonance images. Cereb Cortex 1996; 6: 726-36. [CrossRef]

40. Meaney MJ, McEwen BS. Testosterone implants into the amygdala during the neonatal period masculinize the social play of juvenile female rats. Brain Res 1986; 398: 324-8. [CrossRef]

41. Mozley L, Gur R, Mozley P, Gur R. Striatal dopamine transporters and cognitive functioning in healthy men and women. Am J Psychiatry 2001; 158: 1492-9. [CrossRef]

42. Laakso A, Vilkman H, Bergman J, Haaparanta M, Solin O, Syvalahti $\mathrm{E}$, et al. Sex differences in striatal presynaptic dopamine synthesis capacity in healthy subjects. Biological Psychiatry 2002; 52: 759-63. [CrossRef]

43. Andersen SL, Teicher MH. Sex differences in dopamine receptors and their relevance to ADHD. Neurosci Biobehav Rev 2000; 24: 137-41. [CrossRef]

44. Riccardi P, Zald D, Li R, Park S, Ansari MS, Dawant B, et al. Sex differences in amphetamine-induced displacement of [(18)F] fallypride in striatal and extrastriatal regions: a PET study. Am J Psychiatry 2006; 163: 1639-41.[CrossRef]

45. Rosecrans JA. Differences in brain area 5-hydroxytryptamine turnover and rearing behavior in rats and mice of both sexes. Eur $\mathrm{J}$ Pharmacol 1970; 9: 379-82. [CrossRef]

46. Ortiz J, Artigas F, Gelpi E. Serotonergic status in human blood. Life Sci 1988; 43: 983-90. [CrossRef]

47. Nishizawa S, Benkelfat C, Young SN, Leyton M, Mzengeza S, de Montigny $\mathrm{C}$, et al. Differences between males and females in rates of serotonin synthesis in human brain. Proc Natl Acad Sci USA 1997; 94: 5308-13. [CrossRef]

48. Parsey RV, Oquendo MA, Simpson NR, Ogden RT, Van Heertum $\mathrm{R}$, Arango V, et al. Effects of sex, age, and aggressive traits in man on brain serotonin 5-HT1A receptor binding potential measured by PET using [C-11]WAY-100635. Brain Res 2002; 954: 173-82. [CrossRef]

49. Yoshida T, Kuwabara Y, Sasaki M, Fukumura T, Ichimiya A, Takita $\mathrm{M}$, et al. Sex-related differences in the muscarinic acetylcholinergic receptor in the healthy human brain--a positron emission tomography study. Ann Nucl Med 2000; 14: 97-101. [CrossRef]

50. Sanacora G, Mason GF, Rothman DL, Behar KL, Hyder F, Petroff $\mathrm{OA}$, et al. Reduced cortical gammaaminobutyric acid levels in depressed patients determined by proton magnetic resonance spectroscopy. Arch Gen Psychiatry 1999; 56: 1043-7. [CrossRef]

51. Zubieta JK, Dannals RF, Frost JJ. Gender and Age Influences on Human Brain Mu-Opioid Receptor Binding Measured by PET. Am J Psychiatry 1999; 156: 842-8. 